Article

\title{
Pro- and Anti-Inflammatory Cytokines in the Context of NK Cell-Trophoblast Interactions
}

\author{
Valentina Mikhailova 1,2,*D, Polina Grebenkina ${ }^{1}$, Evgeniia Khokhlova ${ }^{1}$, Alina Davydova ${ }^{1}$, Zeina Salloum ${ }^{1}$, \\ Elizaveta Tyshchuk ${ }^{1}{ }^{\mathbb{D}}$, Valeria Zagainova ${ }^{3}$, Kseniia Markova ${ }^{1}{ }^{\mathbb{D}}$, Igor Kogan ${ }^{3}$, Sergey Selkov ${ }^{1,2}$ \\ and Dmitry Sokolov ${ }^{1,2}$ (D)
}

check for updates

Citation: Mikhailova, V.; Grebenkina, P.; Khokhlova, E.; Davydova, A.; Salloum, Z.; Tyshchuk, E.; Zagainova, V.; Markova, K.; Kogan, I.; Selkov, S.; et al. Pro- and Anti-Inflammatory Cytokines in the Context of NK Cell-Trophoblast Interactions. Int. J. Mol. Sci. 2022, 23, 2387. https:// doi.org/10.3390/ijms23042387

Academic Editor: Daniela Novick

Received: 26 January 2022

Accepted: 18 February 2022

Published: 21 February 2022

Publisher's Note: MDPI stays neutral with regard to jurisdictional claims in published maps and institutional affiliations.

Copyright: (C) 2022 by the authors. Licensee MDPI, Basel, Switzerland. This article is an open access article distributed under the terms and conditions of the Creative Commons Attribution (CC BY) license (https:// creativecommons.org/licenses/by/ $4.0 /)$.
1 Department of Immunology and Intercellular Interactions, Federal State Budgetary Scientific Institution, Research Institute of Obstetrics, Gynecology and Reproductology named after D.O. Ott, 199034 St. Petersburg, Russia; grebenkinap@gmail.com (P.G.); evenka95@gmail.com (E.K.); alyadavydova@gmail.com (A.D.); corbiepost@yandex.ru (Z.S.); tyshhuk.elizaveta@gmail.com (E.T.); kl.markova94@gmail.com (K.M.); selkovsa@mail.ru (S.S.); falcojugger@yandex.ru (D.S.)

2 Department of Immunology, State Budgetary Educational Institution of Higher Professional Education First Pavlov State Medical University of St. Petersburg under the Ministry of Healthcare of the Russian Federation, 197022 St. Petersburg, Russia

3 Department of Artificial Reproduction Technologies, Federal State Budgetary Scientific Institution, Research Institute of Obstetrics, Gynecology, and Reproductology named after D.O. Ott, 199034 St. Petersburg, Russia zagaynovav.al.52@mail.ru (V.Z.); ikogan@mail.ru (I.K.)

* Correspondence: mva_spb@mail.ru; Tel.: +7-(812)-323-75-45

\begin{abstract}
During pregnancy, uterine NK cells interact with trophoblast cells. In addition to contact interactions, uterine NK cells are influenced by cytokines, which are secreted by the cells of the decidua microenvironment. Cytokines can affect the phenotypic characteristics of NK cells and change their functional activity. An imbalance of pro- and anti-inflammatory signals can lead to the development of reproductive pathology. The aim of this study was to assess the effects of cytokines on NK cells in the presence of trophoblast cells in an in vitro model. We used TNF $\alpha, \operatorname{IFN} \gamma, \operatorname{TGF} \beta$ and IL-10; the NK-92 cell line; and peripheral blood NK cells (pNKs) from healthy, non-pregnant women. For trophoblast cells, the JEG-3 cell line was used. In the monoculture of NK-92 cells, TNF $\alpha$ caused a decrease in CD56 expression. In the coculture of NK cells with JEG-3 cells, TNF $\alpha$ increased the expression of NKG2C and NKG2A by NK-92 cells. Under the influence of TGF $\beta$, the expression of CD56 increased and the expression of NKp30 decreased in the monoculture. After the preliminary cultivation of NK-92 cells in the presence of TGF $\beta$, their cytotoxicity increased. In the case of adding TGF $\beta$ to the PBMC culture, as well as coculturing PBMCs and JEG-3 cells, the expression of CD56 and NKp44 by pNK cells was reduced. The differences in the effects of TGF $\beta$ in the model using NK-92 cells and pNK cells may be associated with the possible influence of monocytes or other lymphoid cells from the mononuclear fraction.
\end{abstract}

Keywords: NK cells; trophoblast; NK-92; pNK; JEG-3; TNF $\alpha$; TGF $\beta$; CD56; PBMC

\section{Introduction}

Natural killer cells (NK cells) are cytotoxic, innate immunity lymphocytes that are characterized by the presence of the surface receptors CD45 and CD56, as well as the absence of the linear differentiation receptors CD3, CD14 and CD19 [1]. Mature NK cells predominantly circulate in the peripheral blood ( $\mathrm{pNK}$ ). Resident populations of NK cells are found in lymphoid organs (spleen, tonsils, lymph nodes, Peyer's patches of the intestine and thymus) and non-lymphoid organs (liver, lungs and uterus) [2,3]. One example of tissue-resident cells is uterine NK cells. During pregnancy, NK cells accumulate in the decidual membrane, forming a pool of decidual NK cells (dNKs) [4]. Fewer NK cells reside in the endometrium in non-pregnant women [4]. 
NK cells express various receptors that regulate cytotoxicity towards trophoblast cells $[5,6]$. The receptors have not yet been clearly defined; however, on the basis of their expression, it is possible to separate NK cells into cytotoxic or regulatory populations [7]. The cells of the uteroplacental complex form a cytokine microenvironment that can influence the phenotype and functions of NK cells and regulate their interactions with trophoblast cells.

Extravillous trophoblast cells produce TNF $\alpha$ and its receptors [8], as well as TGF $\beta$ [9]. Under the influence of a conditioned medium from trophoblast cells, peripheral blood monocytes differentiate into macrophages that are similar in their characteristics to the macrophages of the decidua and produce TGF $\beta$ [10]. Through the secretion of TGF $\beta$, decidual macrophages can suppress the cytotoxic activity of decidual NK cells [11]. TGF $\beta$ stimulates the acquisition of $\mathrm{pNK}$ features that are characteristic of dNK cells [12] and also affects the functions of NK cells [13]. In addition, TGF $\beta$ reduces IFN $\gamma$ secretion by NK cells, blocks signals from the NKG2D and CD244 receptors of NK cells and contributes to a decrease in the expression of NKp30. As a result, the cytotoxic activity of NK cells ultimately decreases $[14,15]$.

First-trimester decidua macrophages secrete IL-10, TNF $\alpha$ and IFN $\gamma$ [16-19]. The IL-10 receptor consists of two subunits and is expressed on many cells, including NK cells [19]. IL10 inhibits the cytotoxic and secretory functions of NK cells [20]. The increased production of IFN $\gamma$ and TNF $\alpha$ by macrophages leads to the increased apoptosis of trophoblast cells [16]. It has been shown in mice that IFN $\gamma$ stimulates a multidirectional change in inhibitory receptor expression in pNK cells [21].

In addition to microenvironment cell cytokines, $\mathrm{NK}$ cells can directly synthesize cytokines. It has been shown that CD56+ pNK cells produce IFN $\gamma$, TNF $\alpha$ and TGF $\beta$ in the first trimester of pregnancy [22]. Some populations of dNK cells synthesize TNF $\alpha$ [12,23,24], IFN $\gamma$ [12,14], TGF $\beta[24]$ and IL-10 $[23,24]$ during the first trimester of physiological pregnancy. An imbalance of pro- and anti-inflammatory cytokines in the uteroplacental complex can lead to the development of reproductive pathology. For example, IL-10 gene expression in the placenta is reduced in preeclampsia [25], while IFN $\gamma$ secretion is increased [26], when compared to normal pregnancy. The increased production of the cytokines IFN $\gamma$ and TNF $\alpha$ by dNK cells and placental macrophages is associated with the development of miscarriage [16,23]. Thus, a wide range of cytokines have been described in the uteroplacental complex, yet there are insufficient data on the effects of cytokines on the phenotype and functional state of NK cells during contact interaction with trophoblast cells. Therefore, the aim of this work was to assess the effects of the cytokines TNF $\alpha$, IFN $\gamma$, TGF $\beta$ and IL-10 on the receptor profile and cytotoxicity of NK cells in coculture with JEG-3 trophoblast cells.

\section{Results}

2.1. Influence of Cytokines on the Phenotype of the NK-92 Cell Line in Monoculture and under Co-Cultivation Conditions with the JEG-3 Cell Line

We used a model system of contact cultivation with trophoblast cells, which we described previously [27]. The phenotype of NK-92 cells was assessed after their cultivation without (hereinafter referred to as monoculture) and in the presence of trophoblast cells (hereinafter referred to as coculture).

2.1.1. Effect of TNF $\alpha$ on the Phenotype of the NK-92 Cell Line in Monoculture and under Co-Cultivation Conditions with the JEG-3 Cell Line

The number of NK-92 cells did not change after the addition of TNF $\alpha$ to the monoculture (Figure 1). In the monoculture, the addition of TNF $\alpha$ resulted in a decrease in the expression of the CD56 receptor by NK-92 cells compared to cultivation without TNF $\alpha$ in both IL-2+ and IL-2-free media (Figure 2a). 
a)

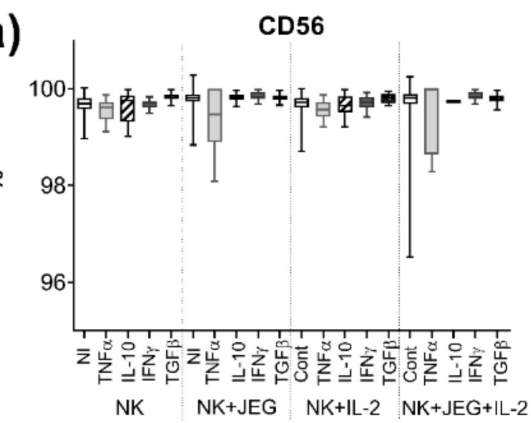

c)

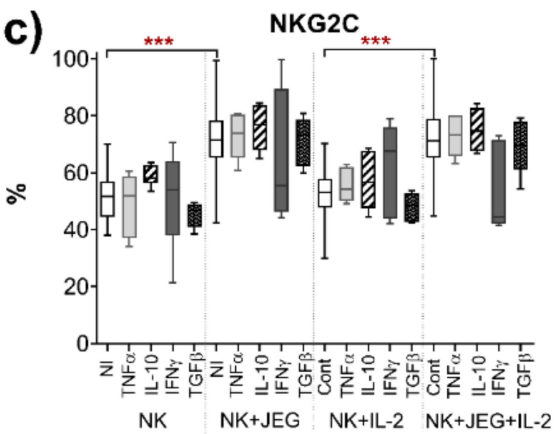

e)

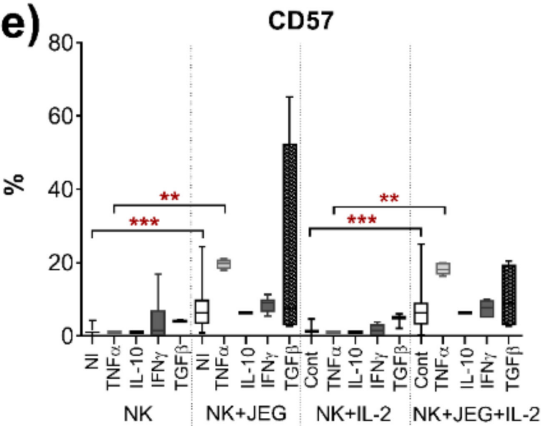

g)

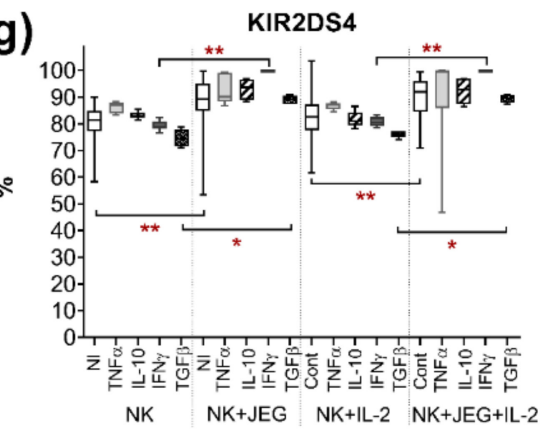

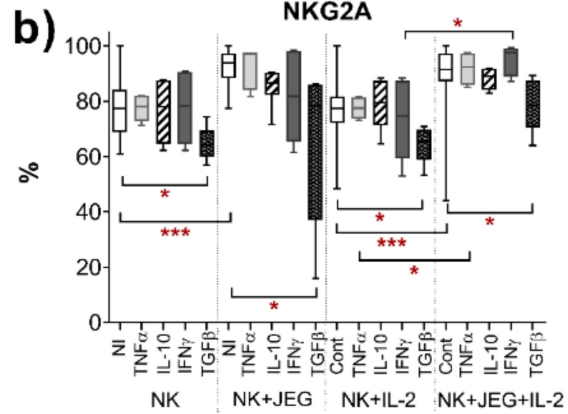

d)
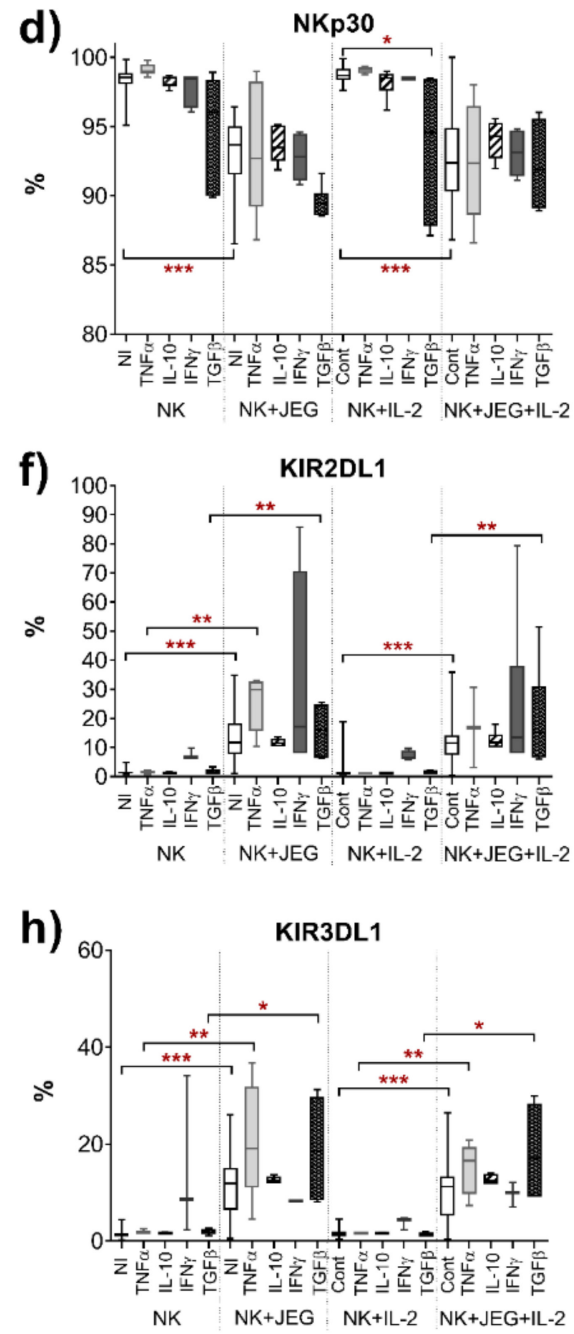

Figure 1. The number of NK-92 cells with phenotypes (a) CD56+, (b) NKG2A+, (c) NKG2C+, (d) NKp30+, (e) CD57+, (f) KIR2DL1+, (g) KIR2DS4+ and (h) KIR3DL1+ after culturing in monoculture and coculture with JEG-3 cell line, with cytokines TNF $\alpha$, IL-10, IFN $\gamma$ and TGF $\beta$. NI (no inducer)—cultured without inducers. Cont (control)—cultured with IL-2. The experiments with each of the cytokines were conducted separately, twice, with three replicates for each experiment. Significant differences: ${ }^{*}-p<0.05,{ }^{* *}-p<0.01$ and ${ }^{* * *}-p<0.001$ (Kruskal-Wallis test). 
a)

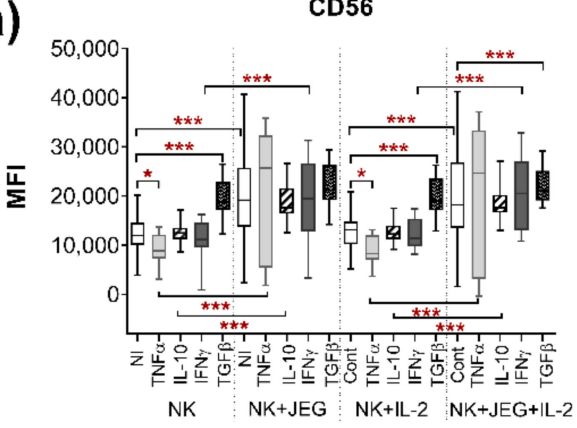

NKG2C

c)

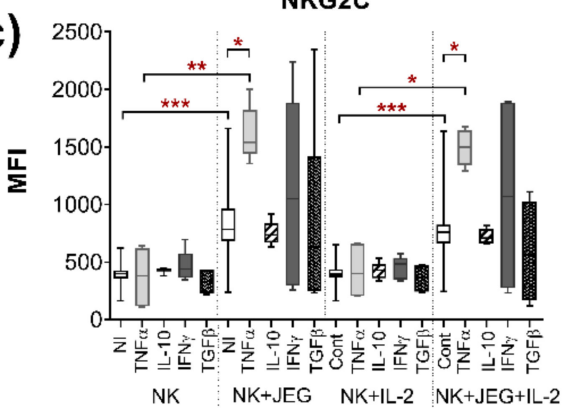

CD57

e)

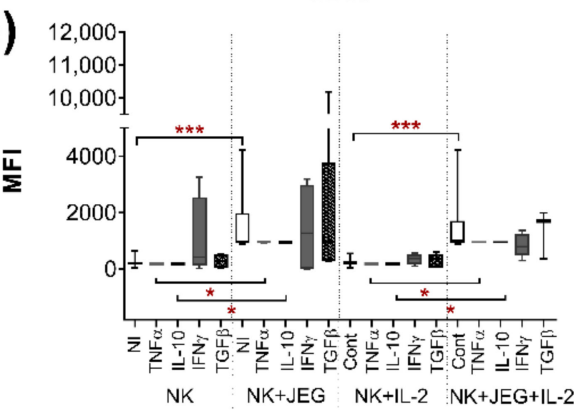

KIR2DS4

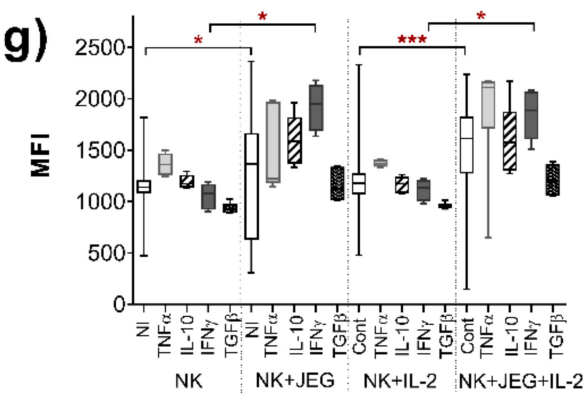

b)

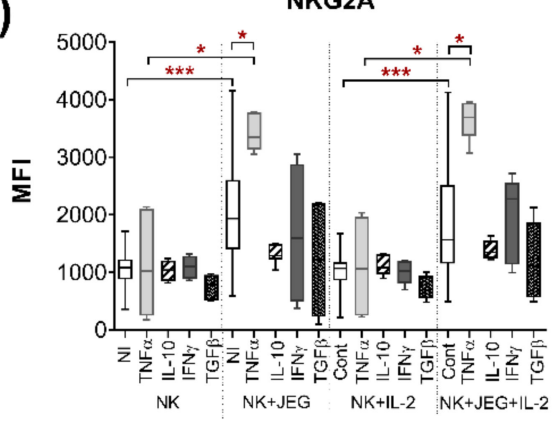

NKp30

d)

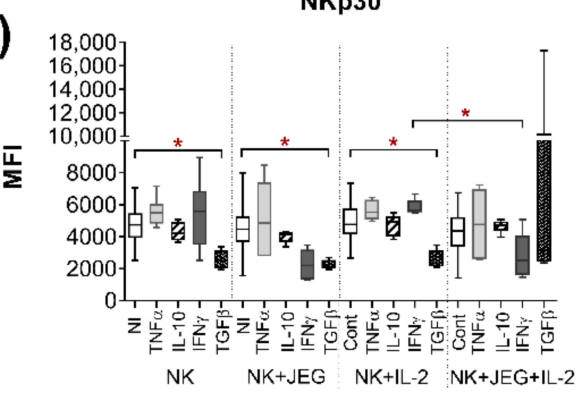

KIR2DL1
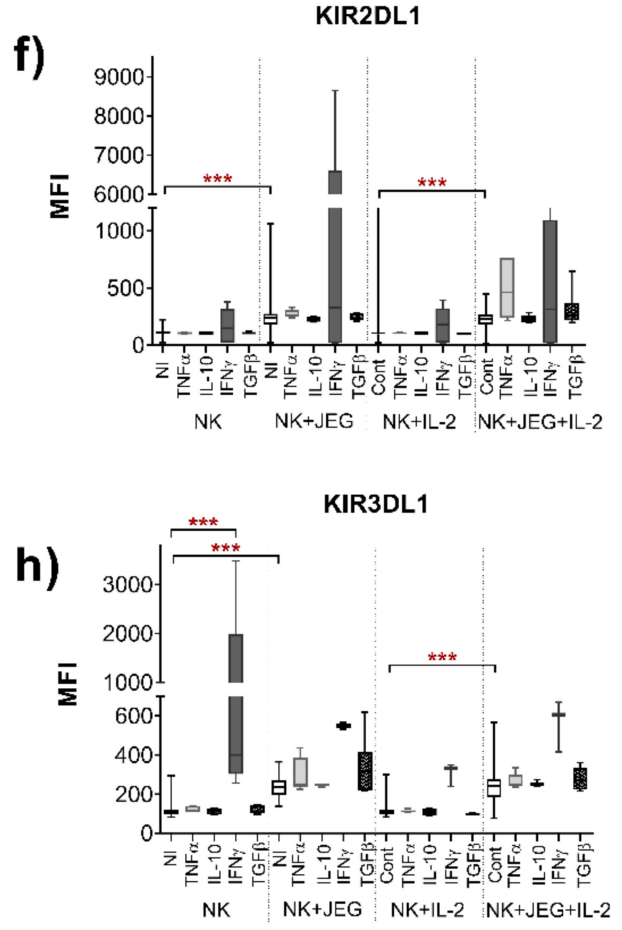

Figure 2. The intensity of (a) CD56, (b) NKG2A, (c) NKG2C, (d) NKp30, (e) CD57, (f) KIR2DL1, (g) KIR2DS4 and (h) KIR3DL1 receptor expression by NK-92 cells after culturing in monoculture and coculture with JEG-3 cell line, with cytokines TNF $\alpha$, IL-10, IFN $\gamma$ and TGF $\beta$. NI (no inducer)cultured without inducers. Cont (control)—cultured with IL-2. The experiments with each of the cytokines were conducted separately, twice, with three replicates for each experiment. Significant differences: ${ }^{*}-p<0.05,{ }^{* *}-p<0.01$ and ${ }^{* *}-p<0.001$ (Kruskal-Wallis test).

In the coculture, compared with the monoculture, the number of NK-92 cells with the phenotype CD57+, KIR2DL1+, KIR3DL1+ and CD127+ increased in the presence of TNF $\alpha$ in the culture medium without IL-2 (Figure 1e,f,h and Figure S1h). In the case of culturing in a medium with IL-2 and TNF $\alpha$, the number of NKG2A+, CD57+, KIR3DL1+ and CD127+ 
NK-92 cells increased in the coculture compared to the monoculture (Figure $1 \mathrm{~b}, \mathrm{e}, \mathrm{h}$ and Figure S1h).

In the case of the coculture, the addition of $\mathrm{TNF} \alpha$ led to an increase in the expression of NKG2A and NKG2C receptors compared to the cell coculture without TNF $\alpha$. These changes were revealed after cultivation in media either without IL-2 or with IL-2 (Figure 2b,c).

In the presence of $\mathrm{TNF} \alpha$, the expression of the receptors CD56, NKG2A, NKG2C, CD57 and CD122 by NK-92 cells increased in the coculture compared to the monoculture in media either without IL-2 or with IL-2 (Figure 2a-c,e and Figure S2g).

2.1.2. Effect of IL-10 on the Phenotype of the NK-92 Cell Line in Monoculture and under Co-Cultivation Conditions with the JEG-3 Cell Line

In the case of using medium without IL-2, the addition of IL-10 to the medium caused an increase in the number of KIR2DL3+ and CD161+ cells for the NK-92 cell line in the coculture compared to monoculture (Figure S1c,f). When cultivated in a medium with IL-2 and IL-10, the number of KIR2DL3+ cells of the NK-92 line also increased in the coculture compared to monoculture (Figure S1c).

The expression of the CD56 and CD57 receptors by NK-92 cells increased in the coculture compared to monoculture when using IL-10-containing medium either with IL-2 or without it (Figure 2a,e).

2.1.3. Influence of IFN $\gamma$ on the Phenotype of the NK-92 Cell Line in Monoculture and under Co-Cultivation Conditions with the JEG-3 Cell Line

IFN $\gamma$ caused an increase in the expression of KIR3DL1 by NK cells only in the case of the monoculture of NK-92 cells in a medium without IL-2 (Figure 2h).

In IFN $\gamma$-containing media without IL-2 or with IL-2, the number of NK-92 cells with the KIR2DS4+ and CD161+ phenotype increased in the coculture compared to the monoculture (Figure $1 \mathrm{~g}$ and Figure S1f). In the medium with IL-2 and IFN $\gamma$, we observed that the number of NK-92 cells with the NKG2A+ and CD215+ phenotype also increased in the case of the coculture compared to the monoculture (Figure $1 \mathrm{~b}$ and Figure S1i).

In the medium without IL-2 but with IFN $\gamma$, the expression of the NKp44 receptor by NK-92 cells increased in the case of the coculture compared to the monoculture (Figure S2a). In the presence of IFN $\gamma$, the expression of CD56, KIR2DS4 and CD127 by NK cells increased in the coculture compared to the monoculture, when using the medium either without IL-2 or with IL-2 (Figure 2a,g and Figure S2h). In the medium with IL-2 and IFN $\gamma$, the expression of the NKp30 receptor by NK-92 cells was reduced in the case of the coculture compared to monoculture (Figure 2d).

2.1.4. Effect of TGF $\beta$ on the Phenotype of the NK-92 Cell Line in Monoculture and under Co-Cultivation Conditions with the JEG-3 Cell Line

TGF $\beta$ in monoculture reduced the relative number of NK-92 cells with the NKG2A+ KIR2DL4+ phenotype compared to cultivation without TGF $\beta$, in the case of culturing NK cells in media both without IL-2 and with IL-2 (Figure 1b and Figure S1b). TGF $\beta$ in combination with IL-2 in monoculture led to a decrease in the number of NK-92 cells with the NKp30+ and CD117+ phenotype compared to the monoculture cultured only with IL-2 (Figure $1 \mathrm{~d}$ and Figure S1e). TGF $\beta$ in the monoculture increased the intensity of CD56 expression by NK-92 cells and reduced the intensity of NKp30 expression in the media both without IL-2 and with IL-2 (Figure 2a,d).

The expression of the receptors KIR2DL4, CD161 and CD127 by NK-92 cells increased in the coculture compared to the monoculture in the presence of TGF $\beta$ in the culture media both without IL-2 and with IL-2 (Figure S2b,f,h).

The addition of TGF $\beta$ to the coculture resulted in a decrease in the number of NK-92 cells expressing NKG2A and CD62L compared to the coculture without TGF $\beta$ (Figure $1 \mathrm{~b}$ and Figure S1d). These changes were established using culture media both without IL-2 and with IL-2. 
The number of NK-92 cells with the KIR2DL1+ KIR2DS4+ KIR3DL1+ KIR2DL3+ phenotype increased in the coculture compared to monoculture in medium supplemented with TGF $\beta$ (Figure $1 \mathrm{a}-\mathrm{h}$ and Figure S1c). These changes were established using culture media both without IL-2 and with IL-2.

TGF $\beta$ in medium without IL-2 reduced the intensity of NKp30 expression by NK-92 cells in coculture compared with the coculture without TGF $\beta$ (Figure $2 \mathrm{~d}$ ). In the medium with IL-2, TGF $\beta$ increased the expression of the CD56 receptor by NK-92 cells in coculture compared to the coculture without TGF $\beta$ (Figure 2a). The expression of the CD161 receptor by NK cells increased in the coculture after the addition of TGF $\beta, \operatorname{compared}$ to the coculture without TGF $\beta$, using media both without IL-2 and with IL-2 (Figure S2f).

The results of the assessment of the effects of the cytokines TNF $\alpha$, IL-10, IFN $\gamma$ and TGF $\beta$ are shown in Scheme 1.

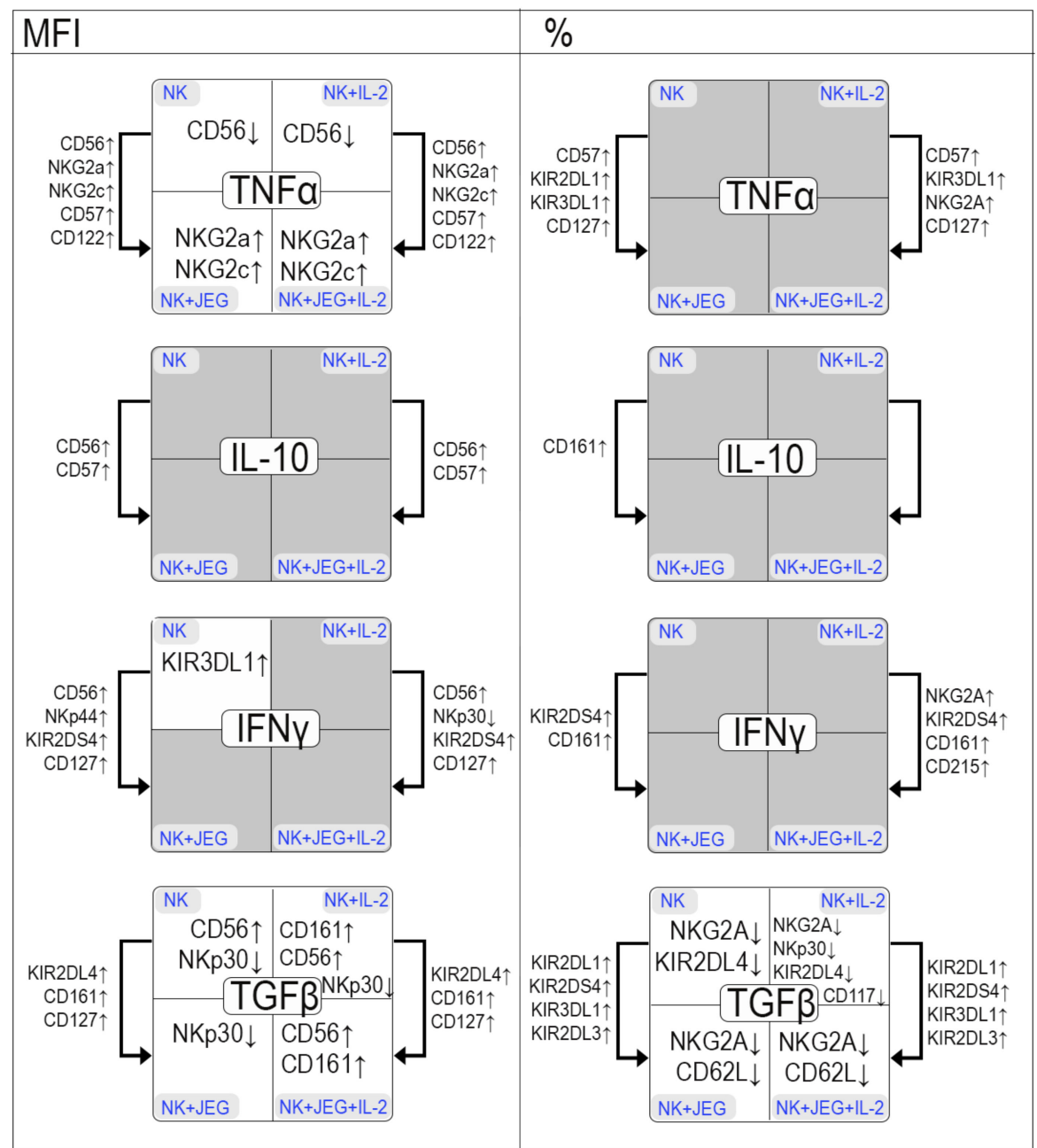

Scheme 1. Effect of TNF $\alpha$, IL-10, IFN $\gamma$ and TGF $\beta$ on NK-92 cells in different culturing variants. The left part of the diagram shows data for the intensity of NK cell expression of receptors (MFI); the right part of the diagram shows data for the number of NK cells. Four cultivation situations are shown in each rectangle: NK cells in monoculture (NK), NK cells cultured with IL-2 (NK+IL-2), NK cells in coculture with JEG-3 trophoblast cells (NK+JEG) and NK cells in coculture with JEG-3 trophoblast cells cultured with IL-2 (NK+JEG+IL-2). Changes in the expression or relative number of NK cells as a result of the addition of a cytokine in each culture situation are shown inside the box. Changes in the expression or number of NK cells in the case of cultivation of cells in coculture compared with monoculture, in the presence of a cytokine in the culture medium, are shown by arrows to the left and right of the rectangles. 


\subsection{Cytotoxicity of NK-92 Cell Line after Culture with Cytokines}

The death of the target cells increased when NK cells were added to JEG-3 trophoblast cells compared to the baseline death levels. After the pre-cultivation of NK cells for $24 \mathrm{~h}$ in the presence of TNF $\alpha$ and IL-10, an increased cytotoxicity of NK cells was found compared to the function of inactivated NK cells (Figure 3a). After the pre-culture of NK cells for $96 \mathrm{~h}$ in the presence of TGF $\beta$, the cytotoxicity of the NK cells was increased compared to the function of unstimulated NK cells (Figure 3b).

\section{a) NK cytotoxicity vs. JEG-3}

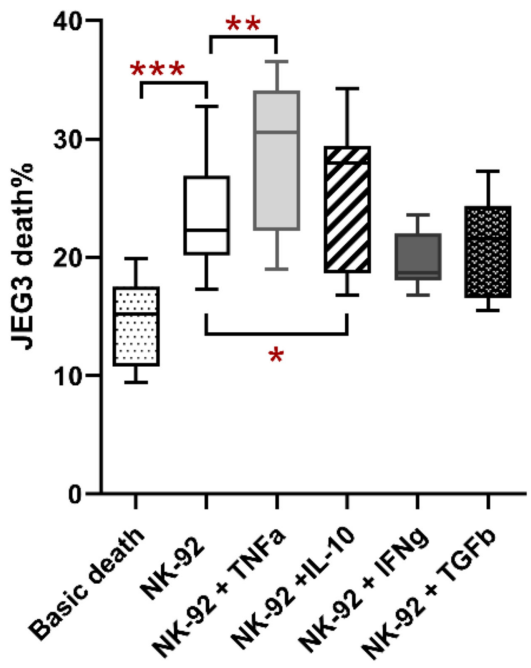

b) NK cytotoxicity vs. JEG-3

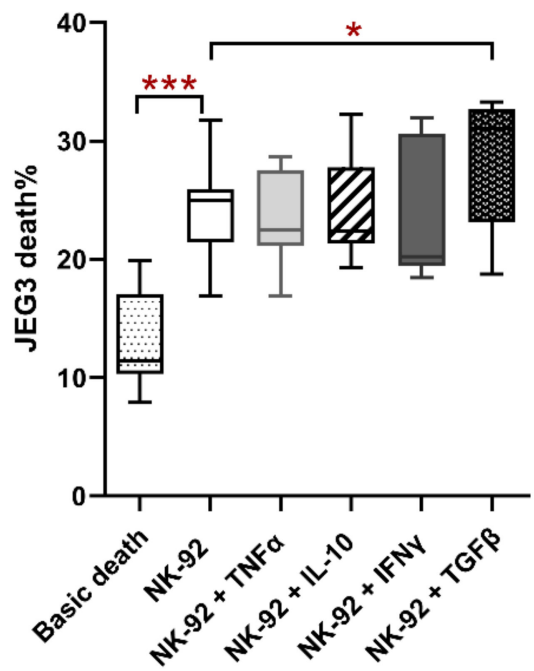

Figure 3. The NK-92 cells' cytotoxicity towards JEG-3 cells after $24 \mathrm{~h}$ (a) and $96 \mathrm{~h}$ (b) of NK cell pre-culturing with cytokines TNF $\alpha$, IL-10, IFN $\gamma$ and TGF $\beta$. Experiments with each cytokine were conducted separately, three times, using four replicates in each experiment. Significant differences: ${ }^{*}-p<0.05,{ }^{* *}-p<0.01$ and $^{* * *}-p<0.001$ (Kruskal-Wallis test).

\subsection{Phenotype of Peripheral Blood NK Cells in Monoculture and under Co-Cultivation Conditions} with the JEG-3 Cell Line

The analysis of the phenotype of pNK cells before cultivation revealed no differences between two subgroups of healthy, non-pregnant women. In this regard, all the examined women were combined into one group to assess the effect of the JEG-3 trophoblast cell line on pNK cells. Since both the phenotypic profile of NK-92 cells and their cytotoxicity changed after a 96-h cultivation in the presence of TGF $\beta$, this cytokine was chosen to analyze phenotypic changes in a system using peripheral blood NK cells. Figure 4 shows representative graphs for CD56 expression by NK-92 cells and pNK cells.

After the cultivation of peripheral blood mononuclear cells (PBMC) with TGF $\beta$, the number of pNK cells with the phenotype NKp44+ and KIR2DS4+ (Figure 5c,d) and the expression of CD56, KIR2DL1 and KIR2DS4 (Figure 6) were reduced compared to unstimulated $\mathrm{pNK}$ cells. 

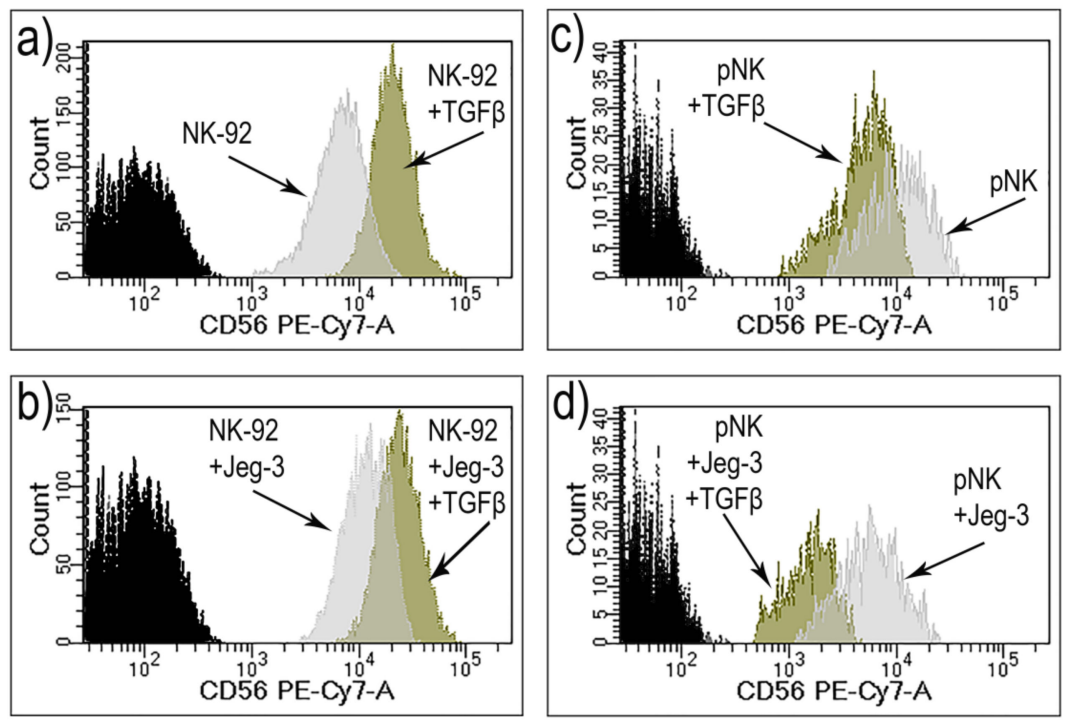

Figure 4. The intensity of CD56 receptor expression by NK-92 cells $(\mathbf{a}, \mathbf{b})$ and peripheral blood NK cells (c,d). Cells were cultured without inducers (grey) and with TGF $\beta$ (dark green). Isotype control is shown in black.

a)

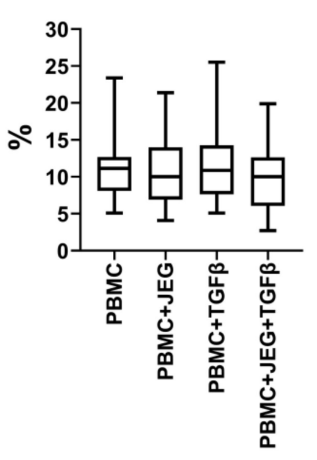

c)

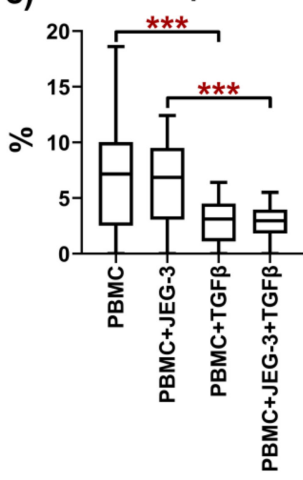

b) NKG2C

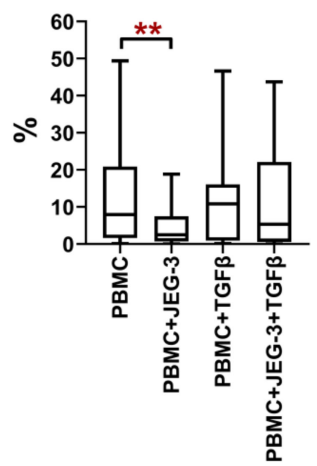

d)

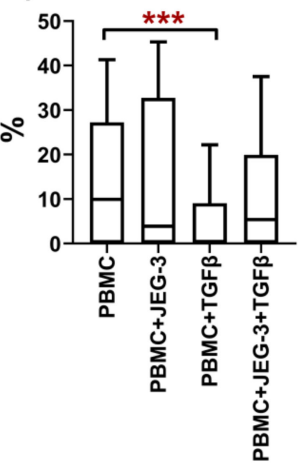

Figure 5. The number of pNK cells with (a) CD56+, (b) NKG2C+, (c) NKp44+ and (d) KIR2DS4+ phenotypes after monoculture without inducers (peripheral blood mononuclear cells (PBMC)) and with TGF $\beta$ (PBMC + TGF $\beta$ ), and in coculture with JEG-3 cells without cytokines (PBMC + JEG-3) and with TGF $\beta$ (PBMC + JEG-3 + TGF $\beta$ ). PBMCs were collected from healthy, non-pregnant women $(n=21)$. Significant differences: ${ }^{* *}-p<0.01$ and ${ }^{* *}-p<0.001$ (Wilcoxon matched-pairs rank test). 
a)

CD56
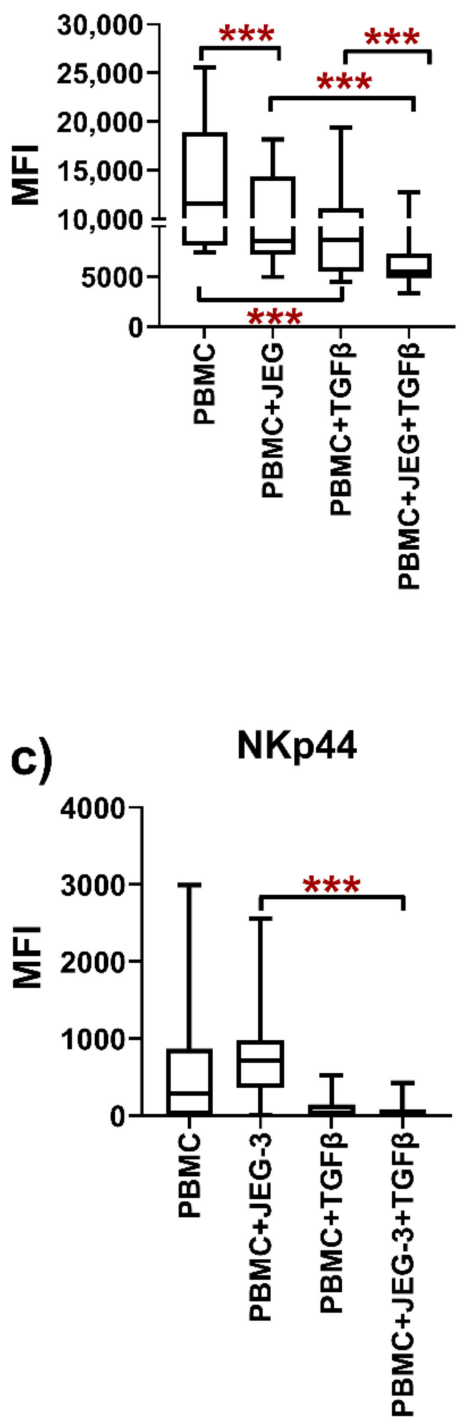
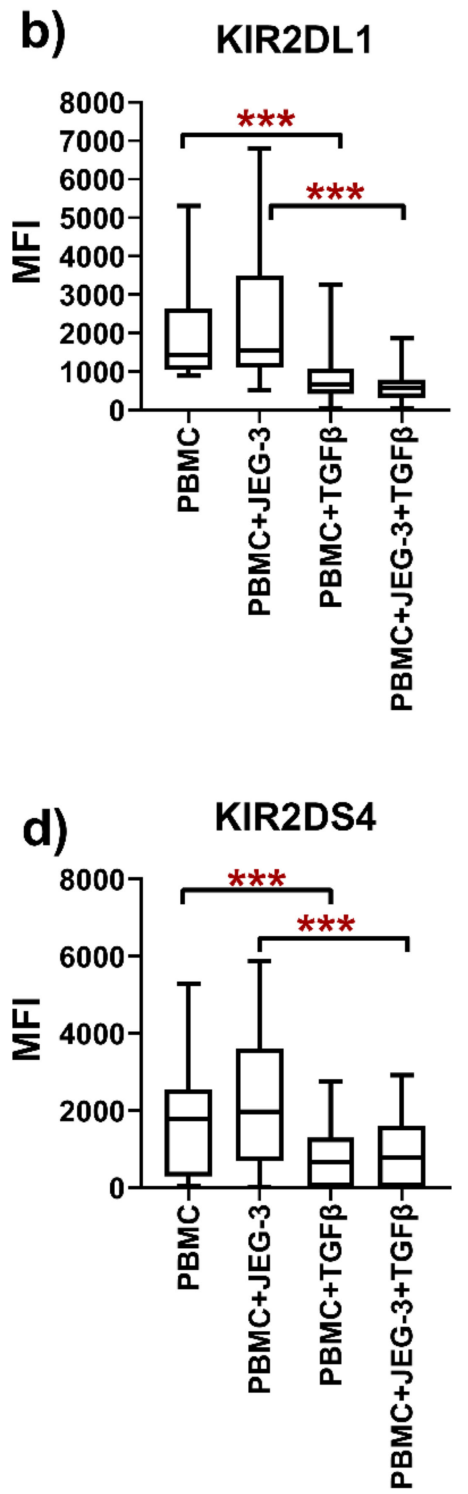

Figure 6. The intensity of (a) CD56, (b) KIR2DL1, (c) NKp44 and (d) KIR2DS4 receptor expression by pNK cells after monoculture without inducers (PBMC) and with TGF $\beta$ (PBMC + TGF $\beta$ ), and in coculture with JEG-3 cells without cytokines (PBMC + JEG-3) and with TGF $\beta$ (PBMC + JEG-3 + TGF $\beta)$. PBMCs were collected from healthy, non-pregnant women $(n=21)$. Significant differences: $* * *-p<0.001$ (Wilcoxon matched-pairs rank test).

After culturing with JEG-3 trophoblast cells, the number of pNK cells with the NKG2C+ phenotype and the expression of CD56 by pNK cells were reduced compared to the cells cultivated without trophoblasts (Figure 5a).

After culturing mononuclear cells in the presence of trophoblast cells and TGF $\beta$, the number of NKp44+ pNK cells (Figure 5) and the expression of the CD56, KIR2DL1, NKp44 and KIR2DS4 receptors by NK cells were reduced compared to pNK cells in coculture with JEG-3 trophoblast cells without the addition of TGF $\beta$ (Figure 6).

The intensity of CD56 expression by pNK cells was reduced in the case of the cultivation of mononuclear cells in a medium containing TGF $\beta$ with JEG-3 trophoblast cells, compared with a monoculture of PBMCs in a medium with TGF $\beta$ (Figure 6). 


\section{Discussion}

$\mathrm{TNF} \alpha$ is a pleiotropic cytokine [28]. TNF $\alpha$ enhances the activating effect of IL-2 and also stimulates the cytotoxicity of NK cells against target cells in vitro [29,30]. We showed that cultivation with TNF $\alpha$ reduced the expression of CD56 by NK-92 cells. We also found that, after pre-cultivation with TNF $\alpha$ for $24 \mathrm{~h}$, the cytotoxicity of NK-92 cells against JEG-3 trophoblast cells was enhanced. These changes in cell phenotype and function can be regarded as the induction of the CD56dim cytotoxic phenotype in the presence of TNF $\alpha$.

It has been reported that NK cells, after in vitro cultivation in the presence of feeder cells expressing membrane-bound IL-21, can change their phenotype and begin to express NKG2C and CD57 receptors, retaining their ability to induce cytotoxicity [31]. These changes, together with the acquisition of HLA-DR, are regarded as being characteristic of adaptive NK cells [31]. In women with previous pregnancies, "pregnancy-trained" decidual NK cells have been described, which are characterized by the increased expression of NKG2C [32]. Endometrial NK cells have been shown to express more NKG2A than pNK cells [33]. In the present work, in the case of culture with JEG-3 trophoblast cells, the addition of $\mathrm{TNF} \alpha$ caused the increased expression of the activating receptor NKG2C and the inhibitory receptor NKG2A. An increased number of CD57+ NK-92 cells and increased expression of CD57 were also found in the case of coculture compared to monoculture. These changes in the NK-92 cell line phenotype after exposure to trophoblast cells may reflect the regulatory effect of trophoblast cells and the induction of a memory-like NK cell phenotype in the case of pregnancy. TNF $\alpha$ is produced by endometrial cells in the secretory phase of the menstrual cycle [34], as well as by dNK cells in the first trimester of pregnancy [23]. In this regard, the effect of $\mathrm{TNF} \alpha$ in combination with the contact interaction with trophoblast cells cannot be regarded solely as pro-inflammatory.

At the same time, it is known that the secretion of TNF $\alpha$, as well as IFN $\gamma$, by dNK cells is increased in spontaneous miscarriage [23]. However, we found that the cytotoxicity of NK cells against JEG-3 cells after the preliminary cultivation of NK-92 cells for $96 \mathrm{~h}$ in the presence of $\mathrm{TNF} \alpha$ did not change compared to that for non-activated NK cells. It is likely that the absence of changes in the cytotoxicity of NK cells against JEG-3 cells after cultivation with TNF $\alpha$ is associated with a short-term effect of the activation of NK-92 cells and the loss of the activated state after a 96-h incubation.

Another pro-inflammatory NK cell cytokine is IFN $\gamma$. We found that IFN $\gamma$ caused an increase in the expression of the activation receptor KIR3DL1 by NK-92 cells in monoculture. After cultivation in a medium with IFN $\gamma$, the effect of trophoblast cells on NK-92 cells was preserved: an increase in the expression of CD56 and KIR2DS4 compared to that in the monoculture was detected. Song $X$. et al. described a correlation between the cytotoxic function of NK-92 cells and their secretion of IFN $\gamma$ upon interaction with K562 target cells [35]. Despite the fact that IFN $\gamma$ is a pro-inflammatory cytokine, we were unable to detect differences between the cytotoxicity of NK cells cultured with IFN $\gamma$ and the activity of unstimulated NK cells against JEG-3 cells. This lack of effect could be associated with both the concentration of IFN $\gamma$ used and the time of cell stimulation. Previously, we found that, in the case of the short-term cultivation of NK-92 cells and JEG-3 cells, IFN $\gamma$ at a similar concentration $(1000 \mathrm{IU} / \mathrm{mL}$ ) caused an increase in the cytotoxic activity of NK cells compared to that of non-activated cells [36]. It has been shown that, in the case of the long-term cultivation (72 h) of JEG-3 cells in the presence of IFN $\gamma$, the expression of HLA-G by trophoblast cells is increased [37]. Thus, according to our data and previously published data, the interaction of NK cells and trophoblast cells in the presence of IFN $\gamma$ does not merely involve contact cytolysis, but also includes changes in the phenotypic characteristics of both NK cells and trophoblast cells, which can also affect their cytotoxic function.

IL-10 is an immunoregulatory cytokine whose production has been demonstrated in dNK cells [38] and decidual macrophages [18]. IL-10 was found to affect the interaction of $\mathrm{dNK}$ cells and the dendritic cells of the uteroplacental complex in a mouse model [39]. We did not establish a direct effect of IL-10 in either the mono- or coculture of the NK-92 and JEG-3 cell lines. With IL-10 in the culture medium, the expression of CD56 and CD57 in NK 
cells increased in the coculture compared to the monoculture. These changes in phenotype indicate the persistent modulating effect of trophoblast cells in the presence of IL- 10 .

In the current study, we found that after $24 \mathrm{~h}$ of preculturing, IL-10 strongly improved the cytotoxic activity of NK-92 cells towards JEG-3 cells. It was previously established that, when IL-10 was added to a model system to assess contact cytolysis by NK cells towards trophoblast cells, it caused an increase in the cytotoxicity of NK-92 cells [36]. After preculturing with IL-10, pNK cells have been shown to possess increased lytic activity against K562 cells [40,41] and an increase in granzyme B content [41]. In addition, in the case of cultivation for $24 \mathrm{~h}$, IL-10 has been shown to reduce the expression of HLA-G by JEG-3 cells [37], which could explain the increased cytotoxicity of NK-92 cells to JEG-3 cells that we observed. Thus, the results obtained are consistent with the data in the literature.

TGF $\beta$, involved in the regulation of many physiological and pathological processes, is one of the most powerful immunosuppressive cytokines [42]. The trophoblast JEG-3 cell line produces TGF $\beta[43,44]$. Co E.C. et al. showed that decidual macrophages, by secreting TGF $\beta$, can reduce the cytotoxicity of NK-92 cells and dNK cells towards K562 cells [11]. We found that under the influence of TGF $\beta, N K$ cells increased the expression of CD56 and also reduced the expression of cytotoxic NKp30 receptors. TGF $\beta$ is reported to suppress the expression of the CD16 receptor by CD56bright NK cells, stimulating the differentiation of CD56bright CD16-NK cells [45]. It has also been shown that TGF $\beta$ inhibits the cytotoxicity of NK cells against dendritic cells by reducing the expression of NKp30 by NK cells [15]. Thus, the changes in CD56 and NKp30 that we established can be regarded as the induction of their regulatory phenotype.

At the same time, according to our data, TGF $\beta$ causes a decrease in the number of NK-92 cells with the NKG2A+ and KIR2DL4+ phenotype in monoculture. Hawke L.G. et al. showed that after $\mathrm{pNK}$ cells were cultured with IL-15 and TGF $\beta$, they acquired an ILC1-like phenotype and an altered expression of the transcription factors Eomes and T-bet [46]. In response to TGF $\beta$ in the culture system with IL-15, the expression of both activating and inhibitory receptors, including NKG2A, by ILC1-like cells increased [46]. Thus, our data complement the earlier results described in the literature.

In coculture with the JEG-3 cell line, TGF $\beta$ also caused an increase in CD56 expression by NK-92 cells, apposing their phenotype to the regulatory one. In the coculture system, TGF $\beta$ also affected trophoblast cells. It has been shown that TGF $\beta$ can stimulate the invasion of JEG-3 trophoblast cells [47]. The inhibition of signaling from TGF $\beta$ in JEG-3 cells leads to a decrease in the proliferation of trophoblast cells [48] and their ability to migrate and invade $[43,49]$. Trophoblast JEG-3 cells express the immunoregulatory glycan-binding protein galectin-1 (Gal1) [50]. Gal1's ligand is T cell Ig and mucin domain-containing protein 3 (Tim-3), expressed by dNK cells [12]. TGF $\beta$ induces the upregulation of Tim-3 expression by dNK cells [12]. The Tim-3/Galecin-9 interaction inhibits the cytotoxicity of NK cells against HTR-8 trophoblast cells [12]. However, we found that after the preliminary cultivation of NK cells in the presence of TGF $\beta$ for $24 \mathrm{~h}$, the death of trophoblast cells did not differ from that for the control.

In a study using mice, TGF $\beta$ suppressed the NK cell-specific transcription factor Eomes in spleen NK cells and induced them to acquire an ILC1-like phenotype [51]. Using ILCs derived from the salivary glands of mice, it was demonstrated that ILC1-like cells contain more granzyme B and C mRNA than NK cells. In knockout mice not expressing TGF $\beta$ R2, granzyme C expression was reduced in ILC1-like cells. [51]. In our work, we detected an increase in the death of JEG-3 cells only after $96 \mathrm{~h}$ of the preliminary incubation of NK cells with TGF $\beta$. It is possible that our results demonstrating the increased cytotoxicity of NK cells after long-term exposure to TGF $\beta$ are associated with the transdifferentiation of NK cells into ILC1 cells with higher cytotoxicity.

In order to confirm the immunomodulatory effect of TGF $\beta$ on NK cells in coculture with trophoblast cells, we assessed the phenotype of pNK cells in our model system. Previously, we found that the cytotoxicity of pNK cells against JEG-3 trophoblast cells decreased during the menstrual cycle, and did not differ in the secretory phase of the cycle from that 
in the first trimester of pregnancy [44]. In this regard, to assess the effect of trophoblast cells on the pNK phenotype, we used PBMCs from healthy women, obtained in the second phase of the menstrual cycle. We found that in the presence of the JEG-3 trophoblast cell line, the expression of CD56 by pNK cells and the relative number of NKG2C + pNK cells were reduced. According to data in the literature, macrophages suppress the cytotoxic function of NK cells through the secretion of TGF $\beta[11,52,53]$. PBMCs contain monocytes, which, under cultivation, can differentiate into macrophages. Trophoblast cells can enhance the secretion of cytokines by monocytes/macrophages. Awoyemi T. et al. showed that syncytiotrophoblast microvesicles obtained from healthy pregnant women induced the secretion of a spectrum of cytokines, including TNF $\alpha$, IL-8, IL-6, VEGF, IL-1 $\beta$ and GM-CSF, by monocyte-like cells of the THP-1 line [54]. The combined inhibitory effect of monocytes/macrophages and trophoblast cells explains the observed decrease in the expression of CD56 and the activation receptor NKG2C.

We also detected the reduced expression of CD56 and the activation receptor NKp44, and a reduced number of pNK cells with the NKp44+ phenotype, when TGF $\beta$ was added to a PBMC monoculture as well as to a coculture of PBMCs with JEG-3 cells. However, in our model with NK-92 cells, CD56 expression increased in the monoculture after cultivation with TGF $\beta$. These differences may also be associated with the influence of monocytes on the phenotype of NK cells in PBMCs. This assumption is consistent with the previously established differences in the cytotoxicity of NK cells in PBMCs and NK cells isolated from PBMC fractions [55]. It should be noted that a decrease in the expression of receptors by pNK cells in the presence of TGF $\beta$ affected not only the activation receptors but also an inhibitory receptor-KIR2DL1. The observed decrease in KIR2DL1 expression may have been associated with a general suppression of the expression of many NK cell receptors by trophoblast cells in the presence of monocytes.

We found that in the presence of TGF $\beta$ in the culture medium, pNK cells had a lower expression of CD56 in coculture compared with monoculture. TGF $\beta$ has been reported to inhibit the production of progesterone and estradiol by JEG-3 cells [56]. It has also been shown in vitro that as a result of exposure to pregnancy hormones, including progesterone, estradiol and prolactin, THP-1 cells can change their secretory profile and begin to produce cytokines characteristic of M2 macrophages [57]. It is possible that the inhibitory effect of trophoblast cells and monocytes in the experiments with PBMCs was enhanced by exogenous TGF $\beta$.

\section{Materials and Methods}

\subsection{Cell Cultures}

We used the NK-92 cell line, which reproduces the main features of natural killer cells (NK cells), in addition to the K562 myelogenous leukemia cell line and JEG-3 trophoblast cells (ATCC, Gaithersburg, MD, USA); all cells were cultured in line with the manufacturer's recommendations. All the cell culture experiments were carried out in a humid atmosphere at $37^{\circ} \mathrm{C}$ under $5 \% \mathrm{CO}_{2}$.

\subsection{Peripheral Blood Mononuclear Cells}

This study included 21 non-pregnant women with regular menses and an uncomplicated obstetric-gynecological and somatic history. The age range of the group was $29.1 \pm 6$ years $(\mathrm{M} \pm \mathrm{SD})$. The group was divided into subgroups depending on obstetric histories: healthy, non-pregnant women (subgroup 1, $n=8$ ) and healthy, fertile, non-pregnant women with a history of one or more pregnancies that ended in term delivery (subgroup $2, n=13$ ). Peripheral blood was obtained by venipuncture after an overnight fast, in the secretory phase of the menstrual cycle, after the ultrasound monitoring of ovulation. Blood sampling was carried out in the secretory phase, since we previously showed that NK cells could change their functional activity in relation to trophoblast cells during the menstrual cycle and in the secretory phase, and did not differ in cytotoxicity from the NK cells of pregnant women in the first trimester [58]. The exclusion criteria for both subgroups 
were exacerbations of chronic diseases; the manifestation of acute inflammatory disease, including antiphospholipid syndrome; external genital endometriosis stage 3-4; anomalies in the development of the genital organs; obesity grade 2-3; a hereditary form of high-risk thrombophilia; diabetes mellitus types 1 and 2; hormone therapy (particularly combined oral contraceptives); or refusal to participate in the study program.

\subsection{Cytokines}

The cytokines IL-2 ('Roncoleukine', BioTech, Saint Petersburg, Russia), TNF $\alpha$ (50 IU/mL, R\&D Systems, Minneapolis, MN, USA, cat. 210-TA), IFN $\gamma(1000 \mathrm{IU} / \mathrm{mL}$, R\&D Systems, Minneapolis, MN, USA, cat. 285-IF), TGF $\beta$ (5 ng/mL, R\&D Systems, Minneapolis, MN, USA, cat. 240-B) and IL-10 (10 IU/mL, R\&D Systems, Minneapolis, MN, USA, cat. 217-IL) were utilized as inducers.

4.4. Assessment of the Phenotype of the NK-92 Cell Line after Cultivation with JEG-3 Trophoblast Cells and Cytokines

We used the method described previously in [27]. Before the experiment, JEG-3 cells were introduced into the wells of a flat-bottomed 24 -well plate $(200,000$ cells $/ \mathrm{mL})$ in complete DMEM growth medium (Biolot, St. Petersburg, Russia, cat.1.3.5.). After $24 \mathrm{~h}$, the cells formed a confluent monolayer. Then, NK-92 cells were added to the wells with JEG-3 cells $(200,000$ cells $/ \mathrm{mL})$. IL-2 (500 IU/mL) and one of the cytokines TNF $\alpha$ (50 IU / mL), IL-10 (10 IU / mL), IFN $\gamma(1000 \mathrm{IU} / \mathrm{mL})$ or TGF $\beta(5 \mathrm{ng} / \mathrm{mL})$ were added to the wells. The cells were then cultured for $96 \mathrm{~h}$, after which they were centrifuged $(200 \times g$, $22{ }^{\circ} \mathrm{C}, 10 \mathrm{~min}$ ) and treated with an Fc receptor-blocking reagent (MACS, Teterow, Germany, cat. 130-059-901). Next, the cells were treated with fluorescently-labeled monoclonal antibodies against the phenotypic receptors CD45 (cat. 347464) and CD56 (cat. 557747); cytokine receptors CD127 (cat. 560549), CD122 (cat. 557323) and CD215 (cat. FAB1471N); differentiation receptors CD117 (cat. 333233), CD161 (cat. 556080), CD57 (cat. 333169) and CD62L (cat. 559772); and cytotoxicity receptors CD94/NKG2A (cat. 555889), NKG2C (cat. 748168), NKG2D (cat. 562498), NKp44 (cat. 558564), NKp30 (cat. 558407), KIR2DL3 (cat. FAB2014A), KIR2DL4 (cat. FAB2238P), KIR3DL1 (cat. FAB12251G), KIR2DL1 (cat. FAB1844F) and KIR2DS4 (cat. 564375) (R\&D Systems, Minneapolis, MN, USA; Becton Dickinson, Franklin Lakes, NJ, USA). Isotype antibodies (R\&D Systems, Minneapolis, MN, USA; Becton Dickinson, Franklin Lakes, NJ, USA) were used as a control for nonspecific binding. Receptor expression was assessed on a FACSCanto II flow cytometer (Becton Dickinson, Franklin Lakes, NJ, USA).

\subsection{Evaluation of the Cytotoxicity of the NK-92 Cell Line after Pre-Cultivation with Cytokines}

NK-92 cells were pre-cultured in a 24-well plate in the presence of TNF $\alpha(50 \mathrm{IU} / \mathrm{mL})$, IL-10 (10 IU / mL), IFN $\gamma(1000 \mathrm{IU} / \mathrm{mL})$ or TGF $\beta(5 \mathrm{ng} / \mathrm{mL})$ for $24 \mathrm{~h}$ or $96 \mathrm{~h}$. The incubation with the cytokines was carried out for $24 \mathrm{~h}$, since it was previously established that the incubation of NK-92 cells with the supernatants of placenta samples led to a change in the expression of surface cell receptors [59]. The incubation time of $96 \mathrm{~h}$ was chosen to match the conditions of the experiments for the co-cultivation of NK-92 cells and JEG-3 cells. The cells were then centrifuged $\left(200 \times g, 22{ }^{\circ} \mathrm{C}, 10 \mathrm{~min}\right)$ and added to the target cells at a ratio of 5:1 (effector:target), and the cytotoxic function of NK cells was assessed according to the intensity of target cell death. JEG-3 trophoblast cells were used as targets, as described previously [36].

\subsection{Evaluation of the Phenotype of pNK Cells after Cultivation with JEG-3 Trophoblast Cells and Cytokines}

First, $24 \mathrm{~h}$ before the experiment, JEG-3 cells were placed in a 96-well flat-bottom plate, with 20,000 cells per $100 \mu \mathrm{L}$ of complete DMEM growth medium (BioloT, St. Petersburg, Russia, cat.1.3.5.). One day later, peripheral blood mononuclear cells (PBMCs) were isolated from peripheral blood using the standard method of centrifugation in a density gradient solution of Ficoll ( $\rho=1.077$, BioloT, St. Petersburg, Russia, cat.1.2.8.1.). Then, the medium 
was removed from the wells with a trophoblast cell monolayer and PBMCs were placed into the wells at 100,000 cells per $100 \mu \mathrm{L}$ of complete growth medium (DMEM). To maintain the viability of the PBMCs, we added IL-2 $(200 \mathrm{IU} / \mathrm{mL})$ to all the wells, while TGF $\beta$ $(5 \mathrm{ng} / \mathrm{mL})$ was added to some of the wells, and the cells were incubated for $96 \mathrm{~h}$. The plate was then centrifuged for $5 \mathrm{~min}$ at $200 \times g$, at $22^{\circ} \mathrm{C}$. The conditioned medium was removed from the wells, and $100 \mu \mathrm{L}$ of Versene solution (BioloT, St. Petersburg, Russia, cat. 1.2.3.2.) was added. After $3 \mathrm{~min}$, the cells were resuspended, transferred to a round-bottom plate, and then centrifuged at $200 \times g$, at $22{ }^{\circ} \mathrm{C}$, for $5 \mathrm{~min}$. The supernatant was removed, and a reagent for blocking Fc receptors (MACS, Teterow, Germany, cat. 130-059-901) was added to the cells. Then, the cells were treated with monoclonal antibodies against the CD3 (cat. 560176), CD56 (cat. 557747), CD45 (cat. 347464), CD14 (cat. 565283), KIR2DS4 (cat. 564375), CD122 (cat. 557323), CD127 (cat. 560549), NKp44 (cat. 558564), NKG2D (cat. 562498) (Becton Dickinson, Franklin Lakes, NJ, USA), KIR3DL1 (cat. FAB12251G), KIR2DL4 (cat. FAB2238P), KIR2DL3 (cat. FAB2014A), KIR2DL1 (cat. FAB1844F), NKG2C (cat. FAB138P) and CD215 (cat. FAB1471N) (R\&D Systems, Minneapolis, MN, USA) receptors according to the manufacturer's instructions. PNK cells were analyzed in PBMCs as lymphocytes with the CD45+ CD14-CD3- CD56+ phenotype using the previously published gating strategy [27]. To assess cell death, some cells were treated with 7-amino-actinomycin D (7-AAD) (cat. 420403, BioLegend, San Diego, CA, USA). The death of NK cells after cultivation in mono- and coculture was no more than $2 \%$. Isotype antibodies (Becton Dickinson, Franklin Lakes, NJ, USA and R\&D Systems, Minneapolis, MN, USA) were used as controls. Receptor expression was assessed using a FACS Canto II flow cytometer (Becton Dickinson, Franklin Lakes, NJ, USA).

\subsection{Statistical Data Analysis}

The data were statistically processed using the GraphPad Prism 8 program. We used the Shapiro-Wilk test to assess the normality of the data distributions. Using the Bartlett test, we estimated the homogeneity of variances. Due to the variances being unequal, we further used non-parametric statistics for data analysis (Mann-Whitney $U$ test and Kruskal-Wallis test).

\subsection{Ethical Approval}

The research was conducted in line with the Code of Ethics of the World Medical Association (Helsinki Declaration). The local ethical committee of the Research Institute of Obstetrics, Gynecology, and Reproductology named after D.O. Ott approved the research (protocol No. 107).

\section{Conclusions}

Here, we analyzed the effect of TNF $\alpha$, IFN $\gamma$, TGF $\beta$ and IL-10 on the receptor profile and cytotoxic activity of NK cells. The pro-inflammatory cytokines IFN $\gamma$ and TNF $\alpha$ stimulated the cytotoxic phenotype of NK cells. We showed that IFN $\gamma$ promoted an increase in the expression of the activation receptor KIR3DL1 by NK-92 cells. TNF $\alpha$ caused a decrease in CD56 expression by NK-92 cells and stimulated their cytotoxic function. The anti-inflammatory cytokine IL-10 did not affect the expression of receptors by NK-92 cells. In the case of co-cultivation with trophoblast cells, the effect of the cytokines on NK cells was different. TNF $\alpha$ increased the expression of both the activating NKG2C receptor and the inhibitory NKG2A receptor by NK-92 cells. In this regard, TNF $\alpha$ in combination with contact interaction with trophoblast cells has a regulatory effect on NK cells and contributes to the induction of a phenotype similar to that of memory cells. TGF $\beta$, in the case of monoculture and coculture with trophoblast cells, stimulated NK-92 cells to acquire a regulatory phenotype. When TGF $\beta$ was added to a monoculture of PBMCs, as well as to a coculture of PBMCs and JEG-3 cells, a reduced expression of CD56 and the activation receptor NKp44 by pNK cells was revealed. Differences in the effect of TGF $\beta$ in the model using NK-92 cells and pNK cells may be associated with the possible influence of 
monocytes from the mononuclear fraction. Further studies are required to establish the full effect of trophoblast cells on the expression of activating and inhibitory NK cell receptors using primary dNK cells and/or decidual macrophages.

Supplementary Materials: The following supporting information can be downloaded at: https: / / www.mdpi.com/article/10.3390/ijms23042387/s1.

Author Contributions: Conceptualization, V.M. and D.S.; methodology, V.M., E.K. and Z.S.; investigation, V.M., P.G., E.K., Z.S., A.D., K.M., V.Z. and E.T.; formal analysis, V.M. and D.S.; resources, S.S. and I.K.; writing-original draft preparation, V.M.; writing—review and editing, V.M., D.S. and S.S.; visualization, V.M., P.G. and K.M.; supervision, D.S. and S.S.; project administration, V.M. and D.S.; funding acquisition, D.S. and S.S. All of the authors have reviewed and approved the manuscript. All authors have read and agreed to the published version of the manuscript.

Funding: This research was supported by the Russian Science Foundation Grant 21-15-00021 (influence of cytokines on NK-92 line cells after culturing with and without trophoblast cells), the Russian Foundation for Basic Research Grant 20-015-00014 (cytotoxicity of NK-92 line cells after preculturing with cytokines), the Ministry of Science and Higher Education of the Russian Federation, Research Program 1021062512052-5-3.2.2 (clinical material acquisition, influence of cytokines on pNK cells after culturing with and without trophoblast cells).

Institutional Review Board Statement: This study was conducted in accordance with the Declaration of Helsinki and approved by the Local Ethics Committee of the Federal State Budgetary Scientific Institution Research Institute of Obstetrics, Gynecology, and Reproductology named after D.O. Ott (Protocol No. 107, 15 March 2021).

Informed Consent Statement: Informed consent was obtained from all subjects involved in the study.

Data Availability Statement: The data presented in this study are available on request from the corresponding author.

Conflicts of Interest: The authors declare no conflict of interest.

\section{Abbreviations}

7-AAD_7-amino-actinomycin D; dNK-decidual NK cell; ILCs—innate lymphoid cells; NK cell—natural killer cell; pNK—-peripheral blood NK cell; PBMCs—peripheral blood mononuclear cells.

\section{References}

1. Veluchamy, J.P.; Delso-Vallejo, M.; Kok, N.; Bohme, F.; Seggewiss-Bernhardt, R.; van der Vliet, H.J.; de Gruijl, T.D.; Huppert, V.; Spanholtz, J. Standardized and flexible eight colour flow cytometry panels harmonized between different laboratories to study human NK cell phenotype and function. Sci. Rep. 2017, 7, 43873. [CrossRef]

2. Sojka, D.K.; Plougastel-Douglas, B.; Yang, L.; Pak-Wittel, M.A.; Artyomov, M.N.; Ivanova, Y.; Zhong, C.; Chase, J.M.; Rothman, P.B.; Yu, J.; et al. Tissue-resident natural killer (NK) cells are cell lineages distinct from thymic and conventional splenic NK cells. eLife 2014, 3, e01659. [CrossRef]

3. Sun, H.; Sun, C.; Tian, Z.; Xiao, W. NK cells in immunotolerant organs. Cell. Mol. Immunol. 2013, 10, 202-212. [CrossRef]

4. Santoni, A.; Carlino, C.; Stabile, H.; Gismondi, A. Mechanisms underlying recruitment and accumulation of decidual NK cells in uterus during pregnancy. Am. J. Reprod. Immunol. 2008, 59, 417-424. [CrossRef]

5. Kennedy, P.R.; Chazara, O.; Gardner, L.; Ivarsson, M.A.; Farrell, L.E.; Xiong, S.; Hiby, S.E.; Colucci, F.; Sharkey, A.M.; Moffett, A. Activating KIR2DS4 Is Expressed by Uterine NK Cells and Contributes to Successful Pregnancy. J. Immunol. 2016, 197, 4292-4300. [CrossRef]

6. Male, V.; Sharkey, A.; Masters, L.; Kennedy, P.R.; Farrell, L.E.; Moffett, A. The effect of pregnancy on the uterine NK cell KIR repertoire. Eur. J. Immunol. 2011, 41, 3017-3027. [CrossRef]

7. Le Gars, M.; Seiler, C.; Kay, A.W.; Bayless, N.L.; Starosvetsky, E.; Moore, L.; Shen-Orr, S.S.; Aziz, N.; Khatri, P.; Dekker, C.L.; et al. Pregnancy-Induced Alterations in NK Cell Phenotype and Function. Front. Immunol. 2019, 10, 2469. [CrossRef]

8. Otun, H.A.; Lash, G.E.; Innes, B.A.; Bulmer, J.N.; Naruse, K.; Hannon, T.; Searle, R.F.; Robson, S.C. Effect of tumour necrosis factor-alpha in combination with interferon-gamma on first trimester extravillous trophoblast invasion. J. Reprod. Immunol. 2011, 88,1-11. [CrossRef] 
9. Prossler, J.; Chen, Q.; Chamley, L.; James, J.L. The relationship between TGFbeta, low oxygen and the outgrowth of extravillous trophoblasts from anchoring villi during the first trimester of pregnancy. Cytokine 2014, 68, 9-15. [CrossRef]

10. Aldo, P.B.; Racicot, K.; Craviero, V.; Guller, S.; Romero, R.; Mor, G. Trophoblast induces monocyte differentiation into CD14+/CD16+ macrophages. Am. J. Reprod. Immunol. 2014, 72, 270-284. [CrossRef]

11. Co, E.C.; Gormley, M.; Kapidzic, M.; Rosen, D.B.; Scott, M.A.; Stolp, H.A.; McMaster, M.; Lanier, L.L.; Barcena, A.; Fisher, S.J. Maternal decidual macrophages inhibit NK cell killing of invasive cytotrophoblasts during human pregnancy. Biol. Reprod. 2013, 88, 155. [CrossRef] [PubMed]

12. Sun, J.; Yang, M.; Ban, Y.; Gao, W.; Song, B.; Wang, Y.; Zhang, Y.; Shao, Q.; Kong, B.; Qu, X. Tim-3 Is Upregulated in NK Cells during Early Pregnancy and Inhibits NK Cytotoxicity toward Trophoblast in Galectin-9 Dependent Pathway. PLoS ONE 2016, 11, e0147186. [CrossRef] [PubMed]

13. Shi, Y.; Massague, J. Mechanisms of TGF-beta signaling from cell membrane to the nucleus. Cell 2003, 113, 685-700. [CrossRef]

14. Sun, C.; Fu, B.; Gao, Y.; Liao, X.; Sun, R.; Tian, Z.; Wei, H. TGF-beta1 down-regulation of NKG2D/DAP10 and 2B4/SAP expression on human NK cells contributes to HBV persistence. PLoS Pathog. 2012, 8, e1002594. [CrossRef] [PubMed]

15. Castriconi, R.; Cantoni, C.; Della Chiesa, M.; Vitale, M.; Marcenaro, E.; Conte, R.; Biassoni, R.; Bottino, C.; Moretta, L.; Moretta, A. Transforming growth factor beta 1 inhibits expression of NKp30 and NKG2D receptors: Consequences for the NK-mediated killing of dendritic cells. Proc. Natl. Acad. Sci. USA 2003, 100, 4120-4125. [CrossRef]

16. Mezouar, S.; Mege, J.L. Changing the paradigm of IFN-gamma at the interface between innate and adaptive immunity: Macrophage-derived IFN-gamma. J. Leukoc. Biol. 2020, 108, 419-426. [CrossRef]

17. Lash, G.E.; Pitman, H.; Morgan, H.L.; Innes, B.A.; Agwu, C.N.; Bulmer, J.N. Decidual macrophages: Key regulators of vascular remodeling in human pregnancy. J. Leukoc. Biol. 2016, 100, 315-325. [CrossRef]

18. McIntire, R.H.; Ganacias, K.G.; Hunt, J.S. Programming of human monocytes by the uteroplacental environment. Reprod. Sci. 2008, 15, 437-447. [CrossRef]

19. Moore, K.W.; de Waal Malefyt, R.; Coffman, R.L.; O'Garra, A. Interleukin-10 and the interleukin-10 receptor. Annu. Rev. Immunol. 2001, 19, 683-765. [CrossRef]

20. Driessler, F.; Venstrom, K.; Sabat, R.; Asadullah, K.; Schottelius, A.J. Molecular mechanisms of interleukin-10-mediated inhibition of NF-kappaB activity: A role for p50. Clin. Exp. Immunol. 2004, 135, 64-73. [CrossRef]

21. Li, Z.Y.; Song, Z.H.; Meng, C.Y.; Yang, D.D.; Yang, Y.; Peng, J.P. IFN-gamma modulates Ly-49 receptors on NK cells in IFN-gammainduced pregnancy failure. Sci. Rep. 2015, 5, 18159. [CrossRef]

22. Chiba, H.; Fukui, A.; Fuchinoue, K.; Funamizu, A.; Tanaka, K.; Mizunuma, H. Expression of Natural Cytotoxicity Receptors on and Intracellular Cytokine Production by NK Cells in Women with Gestational Diabetes Mellitus. Am. J. Reprod. Immunol. 2016, 75, 529-538. [CrossRef] [PubMed]

23. Liu, J.; Dong, P.; Jia, N.; Wen, X.; Luo, L.; Wang, S.; Li, J. The expression of intracellular cytokines of decidual natural killer cells in unexplained recurrent pregnancy loss. J. Matern. Fetal Neonatal Med. 2020, 1-7. [CrossRef] [PubMed]

24. Hu, Y.; Dutz, J.P.; MacCalman, C.D.; Yong, P.; Tan, R.; von Dadelszen, P. Decidual NK cells alter in vitro first trimester extravillous cytotrophoblast migration: A role for IFN-gamma. J. Immunol. 2006, 177, 8522-8530. [CrossRef]

25. Valencia-Ortega, J.; Zarate, A.; Saucedo, R.; Hernandez-Valencia, M.; Cruz, J.G.; Puello, E. Placental Proinflammatory State and Maternal Endothelial Dysfunction in Preeclampsia. Gynecol. Obstet. Investig. 2018, 84, 12-19. [CrossRef] [PubMed]

26. Liu, H.; Wang, W.; Liu, C. Increased expression of IFN-gamma in preeclampsia impairs human trophoblast invasion via a SOCS1/JAK/STAT1 feedback loop. Exp. Ther. Med. 2021, 21, 112. [CrossRef] [PubMed]

27. Mikhailova, V.; Khokhlova, E.; Grebenkina, P.; Salloum, Z.; Nikolaenkov, I.; Markova, K.; Davidova, A.; Selkov, S.; Sokolov, D NK-92 cells change their phenotype and function when cocultured with IL-15, IL-18 and trophoblast cells. Immunobiology 2021, 226, 152125. [CrossRef]

28. Zelova, H.; Hosek, J. TNF-alpha signalling and inflammation: Interactions between old acquaintances. Inflamm. Res. Off. J. Eur. Histamine Res. Soc. 2013, 62, 641-651. [CrossRef]

29. Favrot, M.; Combaret, V.; Blay, J.Y.; Capdeville, R.; Zhou, D.C.; Clapisson, G.; Chouaib, S.; Franks, C.R.; Philip, T. TNF alpha enhancement of NK and LAK cell functions induced by high-dose IL-2 in human peripheral blood mononuclear cells from patients pretreated with alpha IFN + IL-2. Eur. Cytokine Netw. 1990, 1, 221-227.

30. Mason, A.T.; McVicar, D.W.; Smith, C.A.; Young, H.A.; Ware, C.F.; Ortaldo, J.R. Regulation of NK cells through the 80-kDa TNFR (CD120b). J. Leukoc. Biol. 1995, 58, 249-255. [CrossRef]

31. Kobyzeva, P.A.; Streltsova, M.A.; Erokhina, S.A.; Kanevskiy, L.M.; Telford, W.G.; Sapozhnikov, A.M.; Kovalenko, E.I. CD56(dim) CD57(-) NKG2C(+) NK cells retaining proliferative potential are possible precursors of CD57(+) NKG2C(+) memory-like NK cells. J. Leukoc. Biol. 2020, 108, 1379-1395. [CrossRef] [PubMed]

32. Gamliel, M.; Goldman-Wohl, D.; Isaacson, B.; Gur, C.; Stein, N.; Yamin, R.; Berger, M.; Grunewald, M.; Keshet, E.; Rais, Y.; et al. Trained Memory of Human Uterine NK Cells Enhances Their Function in Subsequent Pregnancies. Immunity 2018, 48, 951-962. [CrossRef] [PubMed]

33. Feyaerts, D.; Kuret, T.; van Cranenbroek, B.; van der Zeeuw-Hingrez, S.; van der Heijden, O.W.H.; van der Meer, A.; Joosten, I.; van der Molen, R.G. Endometrial natural killer (NK) cells reveal a tissue-specific receptor repertoire. Hum. Reprod. 2018, 33, 441-451. [CrossRef] [PubMed] 
34. Van Mourik, M.S.; Macklon, N.S.; Heijnen, C.J. Embryonic implantation: Cytokines, adhesion molecules, and immune cells in establishing an implantation environment. J. Leukoc. Biol. 2009, 85, 4-19. [CrossRef] [PubMed]

35. Song, X.; Xu, C.; Wu, X.; Zhao, X.; Fan, J.; Meng, S. The potential markers of NK-92 associated to cytotoxicity against K562 cells. Biologicals 2020, 68, 46-53. [CrossRef]

36. Bazhenov, D.; Mikhailova, V.; Nikolaenkov, I.; Markova, K.; Salloum, Z.; Kogan, I.; Gzgzyan, A.; Selkov, S.; Sokolov, D. The uteroplacental contact zone cytokine influence on NK cell cytotoxicity to trophoblasts. Gynecol. Endocrinol. Off. J. Int. Soc. Gynecol. Endocrinol. 2020, 36, S1-S6. [CrossRef]

37. Persson, G.; Bork, J.B.S.; Isgaard, C.; Larsen, T.G.; Bordoy, A.M.; Bengtsson, M.S.; Hviid, T.V.F. Cytokine stimulation of the choriocarcinoma cell line JEG-3 leads to alterations in the HLA-G expression profile. Cell. Immunol. 2020, 352, 104110. [CrossRef]

38. Li, T.; Cui, L.; Xu, X.; Zhang, H.; Jiang, Y.; Ren, L.; Yang, C.; Liu, X.; Hu, X. The Role of Tim-3 on dNK Cells Dysfunction During Abnormal Pregnancy With Toxoplasma gondii Infection. Front. Cell Infect Microbiol. 2021, 11, 587150. [CrossRef]

39. Blois, S.M.; Freitag, N.; Tirado-Gonzalez, I.; Cheng, S.B.; Heimesaat, M.M.; Bereswill, S.; Rose, M.; Conrad, M.L.; Barrientos, G.; Sharma, S. NK cell-derived IL-10 is critical for DC-NK cell dialogue at the maternal-fetal interface. Sci. Rep. 2017, 7, 2189. [CrossRef]

40. Schulz, U.; Kreutz, M.; Multhoff, G.; Stoelcker, B.; Kohler, M.; Andreesen, R.; Holler, E. Interleukin-10 promotes NK cell killing of autologous macrophages by stimulating expression of NKG2D ligands. Scand. J. Immunol. 2010, 72, 319-331. [CrossRef]

41. Wang, Z.; Guan, D.; Huo, J.; Biswas, S.K.; Huang, Y.; Yang, Y.; Xu, S.; Lam, K.P. IL-10 Enhances Human Natural Killer Cell Effector Functions via Metabolic Reprogramming Regulated by mTORC1 Signaling. Front. Immunol. 2021, 12, 619195. [CrossRef] [PubMed]

42. Li, M.O.; Wan, Y.Y.; Sanjabi, S.; Robertson, A.K.; Flavell, R.A. Transforming growth factor-beta regulation of immune responses Annu. Rev. Immunol. 2006, 24, 99-146. [CrossRef] [PubMed]

43. Yu, H.; Zhang, W.; Han, P.; Yang, B.; Feng, X.; Zhou, P.; Zhu, X.; Zhou, B.; Chen, W.; Qian, J.; et al. MST4 Regulates EpithelialMesenchymal Transition of Choriocarcinoma by Mediating TGF-beta1 Expression. Onco Targets Ther. 2020, 13, 11935-11946. [CrossRef]

44. Mikhailova, V.A.; Kudryavtsev, I.V.; Serebryakova, M.K.; Milyutina, Y.P.; Demidova, E.S.; Panina, A.N.; Bazhenov, D.O.; Belikova, M.E.; Selkov, S.A.; Sokolov, D.I. Trophoblast cell influence on peripheral blood natural killer cell proliferation and phenotype in non-pregnant women and women in early pregnancy. Immunobiology 2020, 225, 151910. [CrossRef] [PubMed]

45. Allan, D.S.; Rybalov, B.; Awong, G.; Zuniga-Pflucker, J.C.; Kopcow, H.D.; Carlyle, J.R.; Strominger, J.L. TGF-beta affects development and differentiation of human natural killer cell subsets. Eur. J. Immunol. 2010, 40, 2289-2295. [CrossRef] [PubMed]

46. Hawke, L.G.; Mitchell, B.Z.; Ormiston, M.L. TGF-beta and IL-15 Synergize through MAPK Pathways to Drive the Conversion of Human NK Cells to an Innate Lymphoid Cell 1-like Phenotype. J. Immunol. 2020, 204, 3171-3181. [CrossRef]

47. Huang, Z.; Li, S.; Fan, W.; Ma, Q. Transforming growth factor beta1 promotes invasion of human JEG-3 trophoblast cells via TGF-beta/Smad3 signaling pathway. Oncotarget 2017, 8, 33560-33570. [CrossRef]

48. Dietrich, B.; Kunihs, V.; Haider, S.; Pollheimer, J.; Knofler, M. 3-Dimensional JEG-3 choriocarcinoma cell organoids as a model for trophoblast expansion and differentiation. Placenta 2021, 104, 243-246. [CrossRef]

49. Yi, Y.; Cheng, J.C.; Klausen, C.; Leung, P.C.K. TGF-beta1 inhibits human trophoblast cell invasion by upregulating cyclooxygenase2. Placenta 2018, 68, 44-51. [CrossRef]

50. Ramhorst, R.E.; Giribaldi, L.; Fraccaroli, L.; Toscano, M.A.; Stupirski, J.C.; Romero, M.D.; Durand, E.S.; Rubinstein, N.; Blaschitz, A.; Sedlmayr, P.; et al. Galectin-1 confers immune privilege to human trophoblast: Implications in recurrent fetal loss. Glycobiology 2012, 22, 1374-1386. [CrossRef]

51. Cortez, V.S.; Cervantes-Barragan, L.; Robinette, M.L.; Bando, J.K.; Wang, Y.; Geiger, T.L.; Gilfillan, S.; Fuchs, A.; Vivier, E.; Sun, J.C.; et al. Transforming Growth Factor-beta Signaling Guides the Differentiation of Innate Lymphoid Cells in Salivary Glands. Immunity 2016, 44, 1127-1139. [CrossRef] [PubMed]

52. Brownlie, D.; Doughty-Shenton, D.; Soong, D.Y.; Nixon, C.; Carragher, N.O.; Carlin, L.M.; Kitamura, T. Metastasis-associated macrophages constrain antitumor capability of natural killer cells in the metastatic site at least partially by membrane bound transforming growth factor beta. J. Immunother. Cancer 2021, 9, e001740. [CrossRef] [PubMed]

53. Nunez, S.Y.; Ziblat, A.; Secchiari, F.; Torres, N.I.; Sierra, J.M.; Raffo Iraolagoitia, X.L.; Araya, R.E.; Domaica, C.I.; Fuertes, M.B.; Zwirner, N.W. Human M2 Macrophages Limit NK Cell Effector Functions through Secretion of TGF-beta and Engagement of CD85j. J. Immunol. 2018, 200, 1008-1015. [CrossRef] [PubMed]

54. Awoyemi, T.; Motta-Mejia, C.; Zhang, W.; Kouser, L.; White, K.; Kandzija, N.; Alhamlan, F.S.; Cribbs, A.P.; Tannetta, D.; Mazey, E.; et al. Syncytiotrophoblast Extracellular Vesicles From Late-Onset Preeclampsia Placentae Suppress Pro-Inflammatory Immune Response in THP-1 Macrophages. Front. Immunol. 2021, 12, 676056. [CrossRef] [PubMed]

55. Mikhailova, V.A.; Bazhenov, D.O.; Viazmina, L.P.; Agnaeva, A.O.; Bespalova, O.N.; Selkov, S.A.; Sokolov, D.I. Cytotoxic Activity of Peripheral Blood NK Cells towards Trophoblast Cells during Pregnancy. Bull. Exp. Biol. Med. 2019, 166, 567-573. [CrossRef] [PubMed]

56. Luo, S.; Yu, H.; Wu, D.; Peng, C. Transforming growth factor-beta1 inhibits steroidogenesis in human trophoblast cells. Mol. Hum. Reprod. 2002, 8, 318-325. [CrossRef] 
57. Mendoza-Cabrera, M.I.; Navarro-Hernandez, R.E.; Santerre, A.; Ortiz-Lazareno, P.C.; Pereira-Suarez, A.L.; Estrada-Chavez, C. Effect of pregnancy hormone mixtures on cytokine production and surface marker expression in naive and LPS-activated THP-1 differentiated monocytes/macrophages. Innate Immun. 2020, 26, 84-96. [CrossRef]

58. Sokolov, D.I.; Mikhailova, V.A.; Agnayeva, A.O.; Bazhenov, D.I.; Khokhlova, E.V.; Bespalova, O.N.; Gzgzyan, A.M.; Selkov, S.A. NK and trophoblast cells interaction: Cytotoxic activity on recurrent pregnancy loss. Gynecol. Endocrinol. 2019, 35, 5-10. [CrossRef]

59. Bazhenov, D.O.; Khokhlova, E.V.; Viazmina, L.P.; Furaeva, K.N.; Mikhailova, V.A.; Kostin, N.A.; Selkov, S.A.; Sokolov, D.I. Characteristics of Natural Killer Cell Interaction with Trophoblast Cells during Pregnancy. Curr. Mol. Med. 2020, $20,202-219$. [CrossRef] 